\title{
THE EFFECTS OF TOTAL BODY IRRADIATION ON SOME ASPECTS OF HUMAN IRON METABOLISM
}

\author{
By JACK LEVIN,* J. ROBERT ANDREWS AND NATHANIEL I. BERLIN \\ (From the Radiation Branch and the General Medicine Branch of the National Cancer \\ Institute, Bethesda, Md.)
}

(Submitted for publication July 28, 1960; accepted December 1, 1960)

The utilization of radioactive iron to evaluate erythropoietic function in normal and disease states in man is well established (1-8). These studies have demonstrated that the half-time $\left(\mathrm{T}_{\frac{1}{2}}\right)$ of plasma radioiron disappearance and the red cell uptake of radioactive iron are valid parameters of bone marrow function. Many investigators have demonstrated dose-dependent changes in these functions following total body irradiation of the rat (9-14). Similar changes have been noted following total body irradiaton of the burro and sheep (15), and monkey (16).

Loeffler, Collins and Hyman (17) studied four patients who received from 50 to $150 \mathrm{r}$ and did not note significant changes in the $T_{\frac{1}{2}}$ of the plasma radioiron $\left(\mathrm{Fe}^{59}\right)$ disappearance at 3 hours or 7 days. In three patients receiving from 150 to $200 \mathrm{r}$, Collins and Loeffler (18) noted an increase in the $T_{1}$ at varying times after irradiation. In nine patients who had received $200 \mathrm{r}$ to the anterior surface of the body, Loeffler (19) noted an increase in the $T_{\frac{1}{2}}$ which was maximal 48 hours following irradiation. Suit, Lajtha, Oliver and Ellis (20) were unable to determine changes in the iron uptake of human bone marrow irradiated in vivo and then studied in a culture medium with $\mathrm{Fe}^{59}$ administered immediately or 24 hours after irradiation. However, they were able to demonstrate an increase in the $T_{\frac{1}{2}}$ and some decrease in the red cell uptake of iron following $100 \mathrm{r}$ total body irradiation, but only when the $\mathrm{Fe}^{59}$ was administered to their patients 48 to 72 hours after irradiation (21). No changes were noted following 25 to $50 \mathrm{r}$. Sinclair (22) studied $12 \mathrm{pa}$ tients who received $200 \mathrm{r}$, and reported a significant increase in the $T_{\frac{1}{2}}$ in all and a depression of red cell uptake of iron in two-thirds of these patients. One cannot construct a dose-response curve from these studies because of the variation in technique and in the source of radiation utilized.

\footnotetext{
* Current address: Department of Internal Medicine, Yale Medical School, New Haven, Conn.
}

The object of this study was to determine the degree and duration of change in the plasma radioiron disappearance rate and the red cell uptake of radioiron of humans following a known dose of total body irradiation. An attempt was made to determine if the degrees of change following a standard dose of irradiation were constant, and if so, whether such changes could be used immediately after exposure to irradiation to predict and evaluate subsequent erythropoietic depression. The applicability of such changes to the quantification of unknown amounts of radiation, such as those which occur in accidental radiation injury, was also considered.

\section{METHODS AND MATERIALS}

The 10 patients chosen for this study had disseminated Hodgkin's disease, lymphosarcoma, reticulum cell sarcoma, or chronic lymphatic leukemia, all proven by biopsy. None was debilitated or terminally ill or had received any previous therapy. With the exception of the 2 patients with chronic lymphatic leukemia who received $80 \mathrm{r}$ total body irradiation, all patients received $100 \mathrm{r}$ as the initial part of their therapy. Each patient served as his own control, and in the nonleukemic patients, all hematological studies and morphological bone marrows were within normal limits prior to irradiation.

Serial serum iron concentrations and iron-binding capacities on fasting pre-breakfast specimens, hemoglobins, and reticulocyte counts were done in conjunction with the aforementioned studies (23-25). All studies were performed at the same time of day. The clinical effects will not be discussed in this paper. No other treatment was given during the period of observation.

The $T_{\frac{1}{2}}$ of the plasma radioiron disappearance rate and the red cell uptake of radioactive iron were determined by methods previously described $(4,5,26)$. Blood volumes were determined with $\mathrm{Cr}^{51}$-labeled red cells in association with each red cell uptake study according to previously published techniques $(26,27)$.

$\mathrm{Fe}^{59}$ was obtained as ferrous ${ }^{59}$ citrate with a specific activity of at least $2 \mu \mathrm{c}$ per $\mu \mathrm{g}$ of iron. Three to $4 \mu \mathrm{c}$ of $\mathrm{Fe}^{59}$ was added to a volume (approximately $15 \mathrm{ml}$ ) of fresh frozen $A B$ negative plasma that had been previously determined to have at least twice the iron-binding capacity as the amount of iron added. After incubation at room temperature for 10 minutes, to produce siderophilin- 

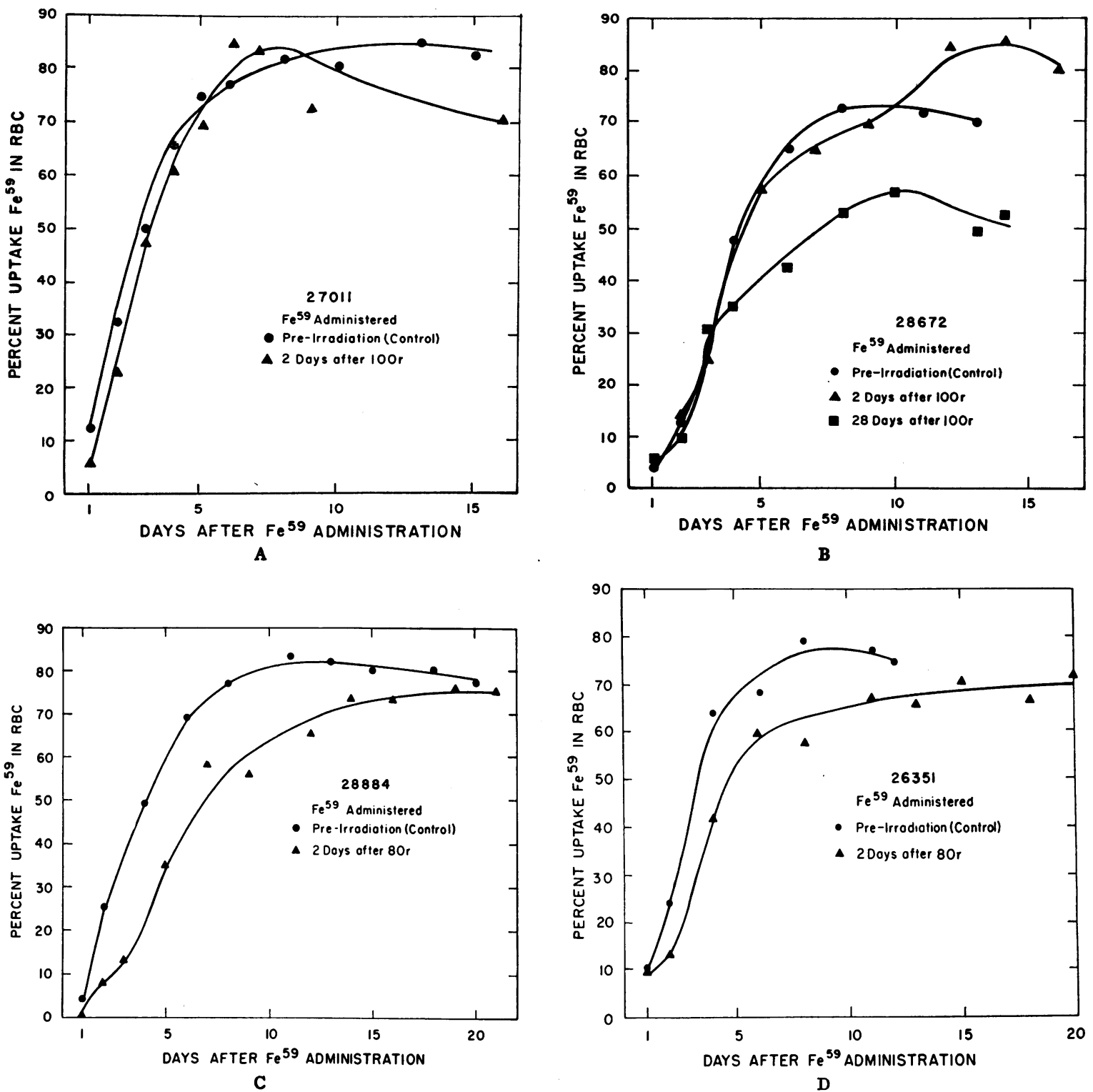

Fig. 1. The efFect of total body irRadiation on the UPtake OF IRON BY THE RED BLOOD CELL.

bound $\mathrm{Fe}^{59}$, a measured volume was injected intravenously. Five-ml samples of whole blood were obtained at appropriate intervals, a maximum of $40 \mathrm{ml}$ being required for a single plasma radioiron disappearance study. ${ }^{1}$ The range of the $T_{\frac{1}{2}}$ and the intervals between studies were such that no significant amount of $\mathrm{Fe}^{58}$ was present in the plasma at the start of a subsequent study. Stable baseline levels of $\mathrm{Fe}^{59}$ in red cells were obtained

1 It is felt that a total of approximately $400 \mathrm{ml}$ (i.e., 10 plasma radioiron disappearance studies) during a period of 50 days did not significantly alter the serum iron concentration in patients who were not bleeding and whose dietary intake was adequate. prior to serial uptake studies. $\mathrm{Fe}^{\mathrm{5 \theta}}$ and $\mathrm{Cr}^{51}$ were counted in a single-channel $\gamma$-ray spectrometer.

The X-rays were generated with a Van de Graff electrostatic accelerator. The patients were irradiated with $2.5 \mathrm{Mev} \mathrm{X}$-rays at a distance of $240 \mathrm{~cm}$, and a dose rate of approximately $25 \mathrm{r}$ per minute. The central axis depth dose was measured in a Masonite phantom, with a suitable condenser $r$-meter. The integrating dosimeter was checked against a calibrated r-meter prior to each treatment. Half of the irradiation was delivered over the anterior surface with the patient supine, and the other half over the posterior surface of the body with the patient prone, in order to achieve a uniform depth dose. The arms and legs were extended. The dose in 
roentgens indicated in our data represents the midline tissue dose in the thickest portion of the body, with the gradients from surface to surface not exceeding 2.5 per cent, and from head to toe not exceeding 4 per cent.

\section{RESULTS}

No change occurred in two cases in the red cell uptake of $\mathrm{Fe}^{59}$ following $100 \mathrm{r}$ when the isotope was administered 2 days following total body irradiation (Figure 1, A and B). However, in one patient (Figure 1B), when the isotope was administered 28 days following irradiation, there was a marked depression in the red cell uptake of $\mathrm{Fe}^{59}$. Despite the lack of change in red cell uptake 2 days following irradiation, these patients did demonstrate a marked change in the rate of plasma iron disappearance. In contrast to these patients with histologically normal marrows, Figure $1, C$ and $\mathrm{D}$ demonstrates changes in red cell uptake of $\mathrm{Fe}^{59}$ administered 2 days after $80 \mathrm{r}$ in two patients with chronic lymphatic leukemia. Because of the apparently greater sensitivity of the $\mathrm{T}_{\frac{1}{2}}$ of the plasma radioiron disappearance as compared to the red cell uptake of $\mathrm{Fe}^{59}$, further attention was primarily concentrated on this variable.

All ten patients studied showed a marked and significant decrease in the plasma radioiron disap-

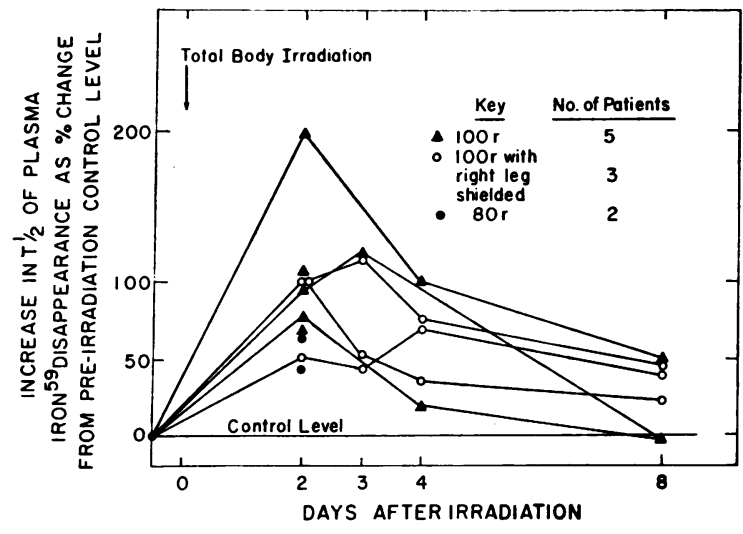

Fig. 2. THE EFFECT OF TOTAL BODY IRRADIATION ON THE $T_{1}$ OF THE PLASMA IRON DISAPPEARANCE RATE IN TEN PATIENTS. Each series of connected points represents an individual patient studied serially.

pearance rate, and hence an increase in the $T_{\frac{1}{2}}, 48$ hours after irradiation (Figure 2). Serial studies revealed that the peak change during the first week occurred in all but one patient between 48 and 72 hours after treatment. By the eighth day, the $\mathrm{T}_{\frac{1}{2}}$ of the plasma $\mathrm{Fe}^{59}$ disappearance had returned to or near the original control level. In addition, there was a second, often greater, degree of change in the rate of plasma radioiron disappearance which occurred in the six patients studied from 22

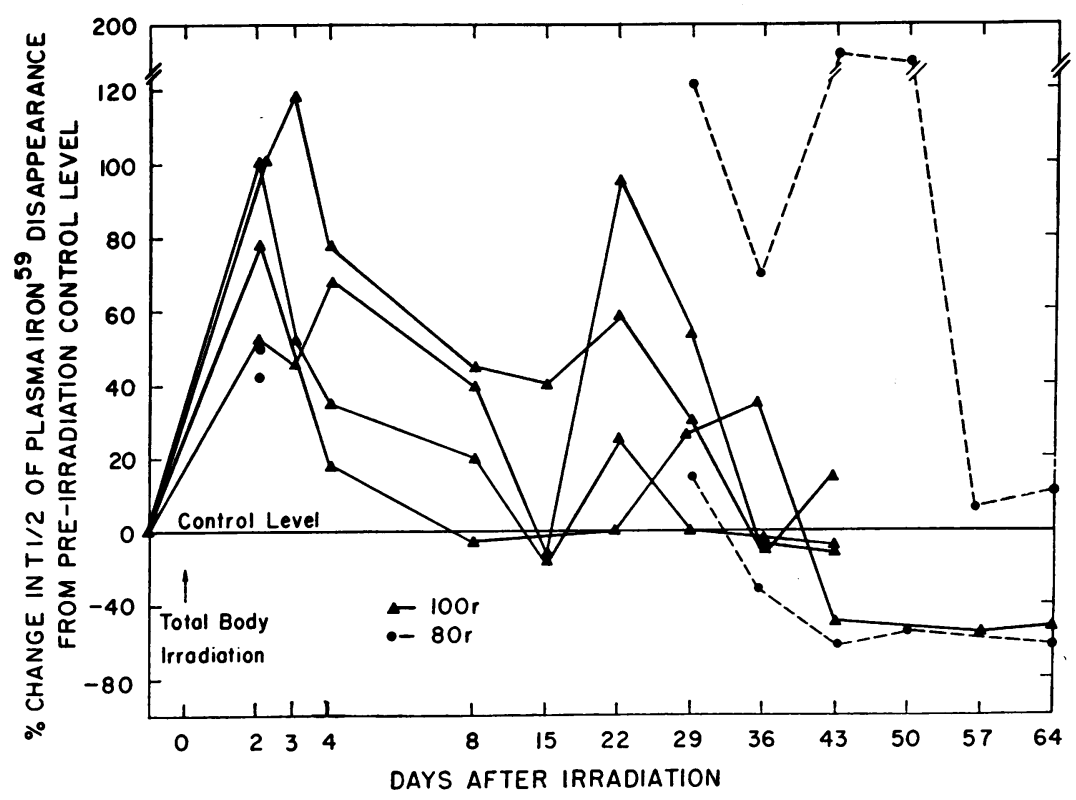

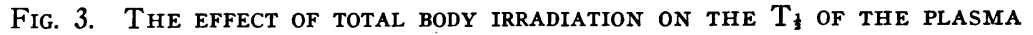
IRON DISAPPEARANCE RATE. Each series of connected points represents an individual patient studied serially. Note that the time scale from 0 to 8 days has been expanded to demonstrate the initial change. 
to 29 days following total body irradiation (Figure 3). There is no obvious explanation of the late third increase in the $T_{\frac{1}{2}}$ of one patient with chronic lymphatic leukemia. Radioiron studies could not be performed between Days 2 and 29 on the two patients with chronic lymphatic leukemia who received $80 \mathrm{r}$ because red cell uptakes were being determined.

TABLE I

Clinical data

\begin{tabular}{|c|c|c|c|c|c|c|c|c|c|c|c|c|c|c|}
\hline & \multirow[b]{2}{*}{ Control } & \multicolumn{13}{|c|}{ Days after irradiation } \\
\hline & & $\mathbf{0}$ & 2 & 3 & 4 & 8 & 15 & 22 & 29 & 36 & 43 & 50 & 57 & 69 \\
\hline \multicolumn{15}{|c|}{ Patient no. 29467, male, 45 yrs; Hodgkin's disease for 24 months } \\
\hline $\begin{array}{l}\mathrm{T}_{\mathbf{1}}(\min ) \\
\mathrm{Fe}(\mu \mathrm{g} \%) \\
\mathrm{Fe} / \mathrm{T}_{\mathbf{1}} \\
\mathrm{Hgb} .(\mathrm{g} \%) \\
\text { Retics }(\%)\end{array}$ & $\begin{array}{c}62 \\
52 \\
0.84 \\
15.9 \\
0.9\end{array}$ & $\begin{array}{r}79 \\
15.3 \\
0.5\end{array}$ & $\begin{array}{c}125 \\
158 \\
1.26 \\
16.3 \\
0.7\end{array}$ & 135 & $\begin{array}{c}110 \\
104 \\
0.95 \\
15.5\end{array}$ & $\begin{array}{l}89 \\
69 \\
0.78 \\
14.9 \\
0.8\end{array}$ & $\begin{array}{l}87 \\
67 \\
0.77 \\
14.9 \\
0.8\end{array}$ & $\begin{array}{l}98 \\
74 \\
0.76 \\
14.0 \\
1.0\end{array}$ & $\begin{array}{l}80 \\
93 \\
1.16 \\
15.4 \\
0.3\end{array}$ & $\begin{array}{c}57 \\
39 \\
0.68 \\
14.1 \\
0.3\end{array}$ & $\begin{array}{l}71 \\
42 \\
0.59 \\
14.3 \\
1.1\end{array}$ & $\begin{array}{r}14.1 \\
1.3\end{array}$ & & \\
\hline \multicolumn{15}{|c|}{ Patient no. 29521, female, 43 yrs; Hodgkin's disease for 3 months } \\
\hline $\begin{array}{l}\mathrm{T}_{\frac{1}{2}}(\min ) \\
\mathrm{Fe}(\mu \mathrm{g} \%) \\
\mathrm{Fe} / \mathrm{T}_{\frac{1}{3}} \\
\mathrm{Hg}(\mathrm{g} \%) \\
\text { Retics }(\%)\end{array}$ & $\begin{array}{l}61 \\
79 \\
1.26 \\
11.7 \\
0.9\end{array}$ & $\begin{array}{l}34 \\
11.4\end{array}$ & $\begin{array}{c}93 \\
121 \\
1.30 \\
11.3 \\
0.8\end{array}$ & 87 & $\begin{array}{c}103 \\
129 \\
1.25 \\
11.4 \\
0.4\end{array}$ & $\begin{array}{c}85 \\
69 \\
0.81 \\
10.1 \\
1.1\end{array}$ & $\begin{array}{r}52 \\
52 \\
1.0 \\
11.9 \\
0.6\end{array}$ & $\begin{array}{c}118 \\
50 \\
0.42 \\
10.8 \\
0.6\end{array}$ & $\begin{array}{l}93 \\
25 \\
0.27 \\
10.5 \\
0.8\end{array}$ & $\begin{array}{l}56 \\
46 \\
0.82 \\
10.7 \\
0.7\end{array}$ & $\begin{array}{l}54 \\
46 \\
0.85 \\
10.2 \\
0.5\end{array}$ & $\begin{array}{r}10.2 \\
0.8\end{array}$ & & \\
\hline \multicolumn{15}{|c|}{$\begin{array}{l}\text { Normal ranges: } \\
\text { T } T_{f}(\min ): 50-110 \\
\text { Serum iron }(\mu \mathrm{g} \%): 100 \pm 20\end{array}$} \\
\hline \multicolumn{15}{|c|}{ Patient no. 28783, female, 40 yrs; giant follicular lymphoma for 17 months } \\
\hline $\begin{array}{l}\mathrm{T}_{1}(\min ) \\
\mathrm{Fe}(\mu \mathrm{g} \%) \\
\mathrm{Fe} / \mathrm{T}_{\frac{1}{2}} \\
\mathrm{Hgb} .(\mathrm{g} \%) \\
\text { Retics }(\%)\end{array}$ & $\begin{array}{c}88 \\
170 \\
1.93 \\
13.4 \\
0.7\end{array}$ & $\begin{array}{r}13.8 \\
0.8\end{array}$ & $\begin{array}{c}156 \\
148 \\
0.95 \\
13.4 \\
1.4\end{array}$ & & $\begin{array}{c}105 \\
155 \\
1.48 \\
13.4 \\
0.6\end{array}$ & $\begin{array}{c}84 \\
128 \\
1.52 \\
12.0 \\
2.7\end{array}$ & $\begin{array}{r}12.1 \\
1.1\end{array}$ & $\begin{array}{c}88 \\
116 \\
1.32 \\
11.0 \\
1.2\end{array}$ & $\begin{array}{c}110 \\
231 \\
2.10 \\
9.9 \\
1.0\end{array}$ & $\begin{array}{c}117 \\
169 \\
1.44 \\
9.9 \\
2.4\end{array}$ & $\begin{array}{c}44 \\
121 \\
2.75 \\
9.9 \\
3.5\end{array}$ & $\begin{array}{r}10.7 \\
2.8\end{array}$ & $\begin{array}{c}38 \\
74 \\
1.95 \\
11.2 \\
1.6\end{array}$ & $\begin{array}{c}42 \\
9(?) \\
0.22 \\
11.0 \\
1.1\end{array}$ \\
\hline \multicolumn{15}{|c|}{ Patient no. 29218, male, $25 \mathrm{yrs}$; lymphoblastic lymphoma for 4 months } \\
\hline $\begin{array}{l}\mathrm{T}(\min ) \\
\mathrm{Fe}(\mu \mathrm{g} \mathrm{\%}) \\
\mathrm{Fe} / \mathrm{T}_{\mathbf{t}} \\
\mathrm{Hgb} .(\mathrm{g} \%) \\
\text { Retics }(\%)\end{array}$ & $\begin{array}{c}94 \\
161 \\
1.71 \\
14.6 \\
0.3\end{array}$ & $\begin{array}{l}95 \\
15.2\end{array}$ & $\begin{array}{c}193 \\
267 \\
1.38 \\
14.9 \\
0.7\end{array}$ & 142 & $\begin{array}{c}128 \\
190 \\
1.48 \\
13.9\end{array}$ & $\begin{array}{c}113 \\
119 \\
1.05 \\
13.9 \\
1.0\end{array}$ & $\begin{array}{l}78 \\
96 \\
1.23 \\
14.0 \\
0.5\end{array}$ & $\begin{array}{c}116 \\
197 \\
1.70 \\
14.8 \\
0.6\end{array}$ & $\begin{array}{c}93 \\
101 \\
1.09 \\
13.6 \\
0.6\end{array}$ & $\begin{array}{c}90 \\
74 \\
0.82 \\
13.9 \\
1.0\end{array}$ & $\begin{array}{l}86 \\
72 \\
0.84 \\
15.1 \\
0.6\end{array}$ & $\begin{array}{r}15.4 \\
0.8\end{array}$ & & \\
\hline \multicolumn{15}{|c|}{ Patient no. 27649, male, $67 \mathrm{yrs}$; reticulum cell sarcoma for 5 months } \\
\hline $\begin{array}{l}\mathrm{T}_{\frac{1}{2}}(\min ) \\
\mathrm{Fe}(\mu \mathrm{g} \mathrm{\%}) \\
\mathrm{Fe} / \mathrm{T}_{\frac{1}{3}} \\
\mathrm{Hgb} .(\mathrm{g} \%) \\
\text { Retics }(\%)\end{array}$ & $\begin{array}{l}63 \\
86 \\
1.37 \\
14.6 \\
0.2\end{array}$ & $\begin{array}{l}148 \\
14.6\end{array}$ & $\begin{array}{c}192 \\
214 \\
1.11 \\
14.4 \\
0.2\end{array}$ & & $\begin{array}{c}121 \\
156 \\
1.30 \\
15.0 \\
0.1\end{array}$ & $\begin{array}{c}99 \\
83 \\
0.84 \\
13.7 \\
0.3\end{array}$ & $\begin{array}{r}12.3 \\
1.3\end{array}$ & $\begin{array}{c}12.4 \\
0.5\end{array}$ & $\begin{array}{r}11.0 \\
0.2\end{array}$ & & & $\begin{array}{r}11.3 \\
1.5\end{array}$ & $\begin{array}{r}12.1 \\
1.2\end{array}$ & \\
\hline \multicolumn{15}{|c|}{ Patient no. 28186, male, 45 yrs; reticulum cell sarcoma for 5 months } \\
\hline $\begin{array}{l}\mathrm{T}_{\frac{1}{2}}(\min ) \\
\mathrm{Fe}(\boldsymbol{\mu g} \%) \\
\mathrm{Fe} / \mathrm{T}_{\ddagger} \\
\mathrm{Hgb} .(\mathrm{g} \%) \\
\text { Retics }(\%)\end{array}$ & $\begin{array}{l}48 \\
67 \\
1.40 \\
13.2 \\
1.8\end{array}$ & $\begin{array}{l}71 \\
14.0\end{array}$ & $\begin{array}{l}93 \\
98 \\
1.05 \\
13.2 \\
1.2\end{array}$ & $\begin{array}{c}106 \\
115 \\
1.08 \\
12.8\end{array}$ & & $\begin{array}{l}40 \\
30 \\
0.75 \\
12.1 \\
0.9\end{array}$ & $\begin{array}{r}10.7 \\
0.9\end{array}$ & $\begin{array}{r}11.4 \\
1.2\end{array}$ & $\begin{array}{l}9.5 \\
1.6\end{array}$ & $\begin{array}{l}8.1 \\
3.4\end{array}$ & $\begin{array}{l}39 \\
67 \\
1.72 \\
8.5 \\
3.4\end{array}$ & $\begin{array}{l}9.2 \\
2.4\end{array}$ & $\begin{array}{r}10.1 \\
3.7\end{array}$ & \\
\hline \multicolumn{15}{|c|}{ Patient no. 28672, male, 65 yrs; lymphosarcoma for 8 months } \\
\hline $\begin{array}{l}\mathrm{T}_{1}(\min ) \\
\mathrm{Fe}(\mu \mathrm{g} \%) \\
\mathrm{Fe} / \mathrm{T}_{\frac{1}{2}} \\
\mathrm{Hgb} .(\mathrm{g} \%) \\
\text { Retics }(\%)\end{array}$ & $\begin{array}{c}51 \\
53 \\
1.04 \\
12.4 \\
0.5\end{array}$ & $\begin{array}{l}49 \\
12.7\end{array}$ & $\begin{array}{l}85 \\
73 \\
0.86 \\
12.3\end{array}$ & $(\mathrm{RBC}$ & $\begin{array}{c}\text { ptake, see } \\
96 \\
11.9 \\
0.8\end{array}$ & $\begin{array}{l}\text { Figure 1B } \\
28 \\
11.9 \\
1.3\end{array}$ & $\begin{array}{l}\text { B) } \\
11.4\end{array}$ & $\begin{array}{r}11.4 \\
0.7\end{array}$ & $\begin{array}{l}95 \\
55 \\
0.58 \\
11.0 \\
0.2\end{array}$ & $\begin{array}{l}9.9 \\
0.5\end{array}$ & $\begin{array}{l}9.5 \\
0.8\end{array}$ & $\begin{array}{l}9.4 \\
1.6\end{array}$ & & \\
\hline \multicolumn{15}{|c|}{ Patient no. 27011, male, 61 yrs; Hodgkin's disease for 3 months } \\
\hline $\begin{array}{l}\mathrm{T}_{t}(\min ) \\
\mathrm{Fe}(\mu \mathrm{g} \%) \\
\mathrm{Fe} / \mathrm{T}_{\frac{1}{2}} \\
\mathrm{Hgb}(\mathrm{g} \%) \\
\text { Retics }(\%)\end{array}$ & $\begin{array}{l}48 \\
60 \\
1.25 \\
13.0\end{array}$ & $\begin{array}{r}41 \\
12.6 \\
1.8\end{array}$ & $\begin{array}{l}98 \\
81 \\
0.83 \\
1.3\end{array}$ & (RBC & $\begin{array}{c}\text { iptake, see } \\
88 \\
13.2 \\
1.2\end{array}$ & $\begin{array}{c}\text { Figure } 1 \mathrm{~A} \\
12.2\end{array}$ & $\begin{array}{l}\text { A) } \\
50 \\
11.8 \\
1.1\end{array}$ & $\begin{array}{r}64 \\
13.4 \\
1.7\end{array}$ & & & $\begin{array}{l}50 \\
74 \\
1.48 \\
10.2 \\
2.2\end{array}$ & $\begin{array}{r}10.2 \\
3.2\end{array}$ & $\begin{array}{l}11.0 \\
2.1\end{array}$ & \\
\hline \multicolumn{15}{|c|}{ Patient no. 28884, female, 75 yrs; chronic lymphatic leukemia for 6 months } \\
\hline $\begin{array}{l}\mathrm{T}(\min ) \\
\mathrm{Fe}(\mu \mathrm{g} \mathrm{\%}) \\
\mathrm{Fe} / \mathrm{T}_{ \pm} \\
\mathrm{Hgb} .(\mathrm{g} \%) \\
\text { Retics }(\%)\end{array}$ & $\begin{array}{c}84 \\
72 \\
0.86 \\
13.6 \\
0.7\end{array}$ & $\begin{array}{r}71 \\
13.4 \\
1.7\end{array}$ & $\begin{array}{c}140 \\
151 \\
1.08 \\
13.3 \\
1.4\end{array}$ & $(\mathrm{RBC}$ & ptake, see & $\begin{array}{r}11.6 \\
1.2\end{array}$ & $\begin{array}{r}11.1 \\
1.4\end{array}$ & $\begin{array}{r}11.9 \\
1.7\end{array}$ & $\begin{array}{l}96 \\
94 \\
0.98 \\
11.0 \\
1.3\end{array}$ & $\begin{array}{l}57 \\
60 \\
1.05 \\
11.0 \\
2.5\end{array}$ & $\begin{array}{c}31 \\
26 \\
0.84 \\
10.7 \\
1.9\end{array}$ & $\begin{array}{l}38 \\
25 \\
0.66 \\
9.8 \\
1.1\end{array}$ & $\begin{array}{r}10.9 \\
3.7\end{array}$ & $\begin{array}{l}27 \\
45 \\
1.66 \\
10.7 \\
2.5\end{array}$ \\
\hline \multicolumn{15}{|c|}{ Patient no. 26351, male, $57 \mathrm{yrs}$; chronic lymphatic leukemia for 6 months } \\
\hline $\begin{array}{l}\mathrm{T}_{1}(\min ) \\
\mathrm{Fe}(\mu \mathrm{g} \%) \\
\mathrm{Fe} / \mathrm{T}_{\mathbf{z}} \\
\mathrm{Hgb} .(\mathrm{g} \%) \\
\text { Retics }(\%)\end{array}$ & $\begin{array}{l}78 \\
99 \\
1.27 \\
1.06 \\
1.3\end{array}$ & 99 & $\begin{array}{c}111 \\
148 \\
1.33 \\
11.2 \\
1.5\end{array}$ & $(\mathrm{RBC}$ & ptake, see & Figure 11 & $\begin{array}{l}9.2 \\
1.1\end{array}$ & $\begin{array}{l}9.5 \\
1.5\end{array}$ & $\begin{array}{c}177 \\
148 \\
0.84 \\
9.7 \\
1.1\end{array}$ & $\begin{array}{c}118 \\
106 \\
0.90 \\
9.9 \\
4.1\end{array}$ & $\begin{array}{c}232 \\
187 \\
0.81 \\
10.4 \\
1.0\end{array}$ & $\begin{array}{c}224 \\
153 \\
0.68 \\
9.5 \\
1.0\end{array}$ & $\begin{array}{l}86 \\
74 \\
0.86 \\
9.7 \\
2.1\end{array}$ & $\begin{array}{c}88 \\
82 \\
0.93 \\
10.4 \\
3.3\end{array}$ \\
\hline
\end{tabular}


As can be seen from the formula for plasma iron turnover:

$0.693 \times 24(\mathrm{hrs}) \times 60(\mathrm{~min}) \times$ serum iron concentration $(\mu \mathrm{c} / \mathrm{ml}) \times$ plasma volume $(\mathrm{ml})$, $T_{1}(\min )$

the two factors which are the most significant variables are the serum iron concentration and the $\mathrm{T}_{\frac{1}{2}}$ of the plasma radioiron disappearance. Assuming that the plasma volume remains stable, the ratio of the serum iron to the $T_{1}$ becomes a measure of erythropoiesis. Table I shows that, although the plasma iron concentration tended to rise following total body irradiation, the degree of change was not proportional in any single patient to the degree of change in the plasma iron disappearance rate, particularly 22 to 35 days following irradiation. Furthermore, the serum iron often varied greatly (Figure 4). This decrease in plasma iron turnover was especially marked during the second period of $\mathrm{T}_{\frac{1}{2}}$ elevation which occured 22 to 29 days after irradiation. Hence, at this time, there was a very marked drop in iron utilization for erythropoiesis.

Unlike changes which have been noted in animals $(11,15,16,28,29)$, no diphasic changes in the serum iron concentrations were noted in the patients studied. There was no significant change in the total iron-binding capacity at any time.

The first increase in the $T_{1}$ preceded any de- crease in the hemoglobin concentration or change in reticulocyte count (Table I). The only significant alteration in the reticulocyte count was an increase occurring 30 to 40 days following irradiation, and associated with erythropoietic regeneration.

Shielding of one leg in three of our patients did not decrease the degree of change seen in the $\mathrm{T}_{1}$ of the plasma radioiron disappearance. This is in contrast to the protection noted by shielding limbs of rats (12). The decrease in hemoglobin concentration and the changes in rate of plasma radioiron disappearance were not associated with bleeding in any of our patients.

\section{DISCUSSION}

The data indicate that unlike changes found in lower animals at similar X-ray dose levels $(9,11$, 13 ), in man the $T_{1}$ of the plasma radioiron disappearance is a more sensitive indicator of hematopoietic damage than is depression of the red cell uptake of iron. Changes in the $\mathrm{T}_{\frac{1}{2}}$ were consistently noted in all patients studied and ap-

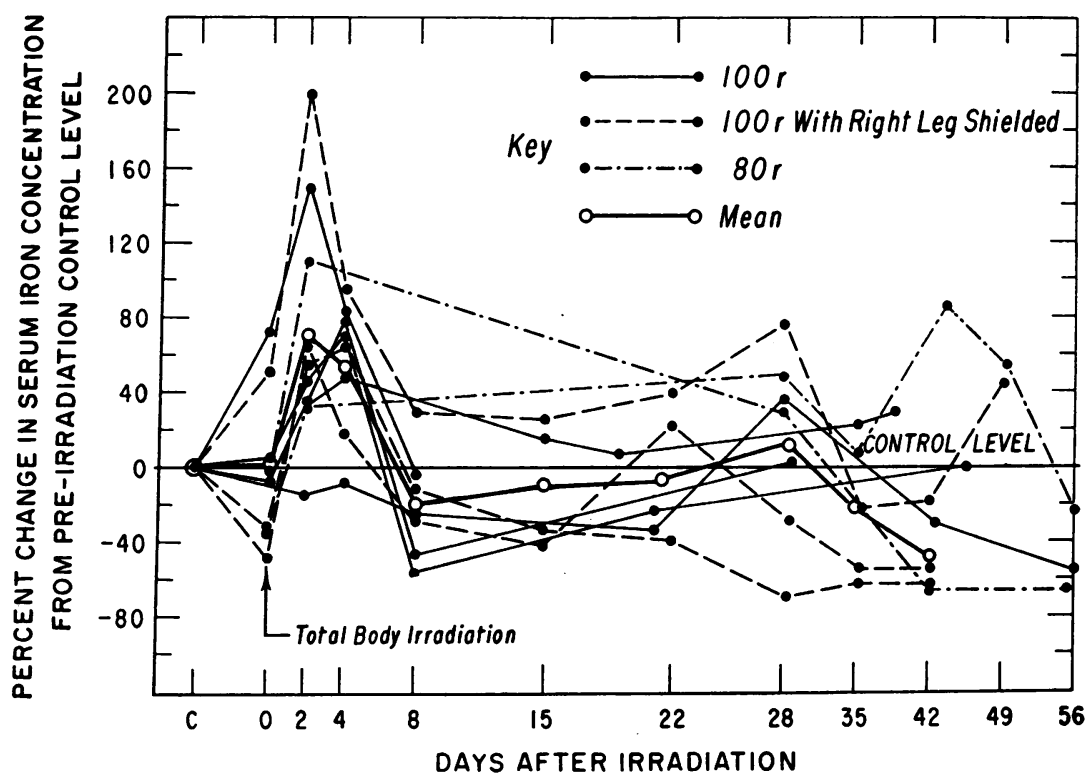

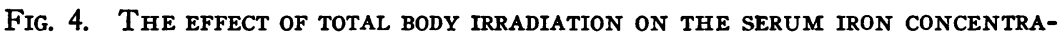
rION. Each series of connected points represents an individual patient studied serially. 
peared to be a valid measure of radiation damage to the bone marrow. This change precedes any change in the peripheral blood count and at this dose level is not eliminated by shielding one leg.

The second increase in the $\mathrm{T}_{\frac{1}{2}}$ of the plasma $\mathrm{Fe}^{59}$ disappearance, not reported previously, indicates that functional changes occur in the erythropoietic system for a longer period following total body irradiation than had been suspected. Since this increase is not associated with marked rises in the serum iron concentration, it represents a period of decreased plasma iron turnover that is more marked than that which occurs during the week immediately following irradiation. This change between Days 22 and 29 is distinct from the first increase noted during the 2 to 3 day period after irradiation, and is preceded by a normal period which clearly separates it from the initial increase. Following the second increase, the $\mathrm{T}_{\frac{1}{2}}$ either returned to the patient's original control level or stabilized at a faster turnover rate (lower $T_{\frac{1}{2}}$ ), presumably indicative of compensatory hyperactivity.

The serum iron concentration varies a great deal in each patient and would not appear to be as reliable an indicator of radiation injury as the $\mathrm{T}_{\frac{1}{2}}$. An indication of this is the change often noted between the initial control level and the determination on the day of irradiation, at which time serum iron levels were obtained prior to irradiation.

The assumption has been made that, although these patients have a malignant tumor, they do have normal bone marrow function, with the exception of the two patients with chronic lymphatic leukemia who had extensive infiltration of their marrow with lymphocytes. It is likely that the changes observed are similar to those which would be observed in normal subjects.

There is currently no universally accepted theory to explain alterations in erythropoietic function following irradiation. Maturation arrest would not explain the diphasic change in the $T_{\frac{1}{2}}$ of the plasma radioiron disappearance. The temporary return to normal from 8 to 20 days after irradiation may represent a compensatory effort on the part of the erythron, which cannot be sustained.

The data indicate marked alterations in function, since increases in the serum iron, when they occur, do not compensate fully for increases in the $T_{\frac{1}{2}}$. The $T_{\frac{1}{2}}$ increased in two patients with normal marrows, although there was no change in their red cell uptake of iron.

It would appear that the $T_{\frac{1}{2}}$ can be used to indicate radiation damage, although the variation in the degree of change at 2 to 4 days, in this group of patients, appears to be too great to permit an exact quantification of unknown amounts of irradiation.

\section{SUM MARY}

Erythropoietic function has been studied in ten patients following 80 to $100 \mathrm{r}$ total body irradiation. The plasma $\mathrm{Fe}^{59}$ disappearance rate was measured serially up to 64 days following irradiation, and red cell uptake of $\mathrm{Fe}^{59}$ was measured in four patients.

All ten patients demonstrated a marked increase in the $T_{\frac{1}{2}}$ of the plasma iron disappearance rate during the week following irradiation. There was a second increase in the $T_{\frac{1}{2}} 22$ to 29 days following irradiation in all six patients studied, indicative of radiation injury and prolonged functional change.

Two patients with normal marrows did not demonstrate changes in their red cell uptake of iron, whereas two patients with chronic lymphatic leukemia had significant depression of uptake.

At this dose level, the $T_{\frac{1}{2}}$ of the plasma radioiron disappearance seems to be a sensitive indicator of radiation damage, is associated with a decrease in plasma iron turnover, and increases prior to changes in the hemoglobin concentration or reticulocyte count.

\section{REFERENCES}

1. Finch, C. A., Gibson, J. G., II., Peacock, W. C., and Fluharty, R. G. Iron metabolism. Utilization of intravenous radioactive iron. Blood 1949, 4, 905.

2. Elmlinger, P. J., Huff, R. L., Tobias, C. A., and Lawrence, J. H. Iron turnover abnormalities in patients having anemia: Serial blood and in vivo tissue studies with $\mathrm{Fe}^{50}$. Acta Haemat. 1953, 9, 73.

3. Huff, R. L., Hennessy, T. G., Austin, R. E., Garcia, J. F., Roberts, B. M., and Lawrence, J. H. Plasma red cell iron turnover in normal subjects and in patients having various hematopoietic disorders. J. clin. Invest. 1950, 29, 1041.

4. Wasserman, L. R., Rashkoff, I. A., Leavitt, D., Mayer, J., and Port, S. Rate of removal of ra- 
dioactive iron from the plasma-An index of erythropoiesis. J. clin. Invest. 1952, 31, 32.

5. Huff, R. L., Tobias, C. A., and Lawrence, J. H. A test for red cell production. Acta Hacmat. 1952, 7, 129.

6. Loeffler, R. K. The radioiron turnover test in clinical medicine. R. I. med. J. 1956, 39, 371.

7. Pollycove, M. Ferrokinetics: Techniques in Sonderdruck aus Eisenstoffwechsel-Beitrage zur Forschung und Klinik, W. Keiderling, Ed. Stuttgart, Georg Thieme Verlag, 1959.

8. Huff, R. L. Erythrocyte formation estimated by radioiron. Meth. med. Res. 1960, 8, 35.

9. Hennessy, T. G., and Huff, R. L. Depression of tracer iron uptake curve in rat erythrocytes following total body X-irradiation. Proc. Soc. exp. Biol. (N. Y.) 1950, 73, 436.

10. Belcher, E. H., Gilbert, I. G. F., and Lamerton, L. F. Experimental studies with radioactive iron. Brit. J. Radiol. 1954, 27, 387.

11. Griffin, E. D., and Alpen, E. L. Iron utilization in the rat exposed to low-dosage whole-body X-irradiation (abstract). Radiat. Res. 1955, 3, 230.

12. Baxter, C. F., Belcher, E. H., Harriss, E. B., and Lamerton, L. F. Anaemia and erythropoiesis in the irradiated rat: An experimental study with particular reference to techniques involving radioactive iron. Brit. J. Haemat. 1955, 1, 86.

13. Harriss, E. B. The effect of whole body irradiation on the bone marrow as studied by radioactive iron incorporation in Radioaktive Isotope in Klinik und Forschung, Band III, K. Fellinger and H. Vetter, Eds. Munich, Urban \& Schwarzenberg, 1958, p. 6.

14. Girvin, E. C., and Hampton, J. K., Jr. Effect of whole body $\mathrm{X}$-irradiation on plasma iron turnover in rats. Proc. Soc. exp. Biol. (N. Y.) 1959, 100, 481.

15. Melville, G. S., and Trum, B. F. Effect of acute whole body gamma irradiation on plasma iron and iron uptake in the burro and the sheep. School Av. Med. 1957, USAF 57-154.

16. Hartwig, Q. L., Melville, G. S., Jr., Leffingwell, T. P., and Young, R. J. Iron-59 metabolism as an index of erythropoietic damage and recovery in monkeys exposed to nuclear radiations. Amer. J. Physiol. 1959, 196, 156.
17. Loeffler, R. K., Collins, V. P., and Hyman, G. A. Comparative effects of total body radiation, nitrogen mustard, and trictlyylene melamine on the hematopoictic system of terminal cancer patients. Science 1953, 118, 161.

18. Collins, V. P., and Loeffler, R. K. The therapeutic use of single doses of total body radiation. Amer. J. Roentgenol. 1956, 75, 542.

19. Loeffler, R. K. Radioiron tracer studies for the evaluation of radiation damage. Amer. J. Roentgenol. 1957, 77, 836.

20. Suit, H. D., Lajtha, L. G., Oliver, R., and Ellis, F. Studies on the ${ }^{59} \mathrm{Fe}$ uptake by normoblasts and the failure of X-irradiation to affect uptake. Brit. J. Haemat. 1957, 3, 165.

21. Suit, H. D., Ellis, F., and Oliver, R. Effect of total body irradiation on iron metabolism in human bone marrow. Brit. J. Radiol. 1957, 30, 553.

22. Sinclair, W. K. Change in plasma clearance rate and red cell uptake of radioactive iron in patients following total body $\mathrm{X}$-irradiation. Int. J. appl. Radiat. 1958, 3, 93.

23. Ness, A. T., and Dickerson, H. C., Jr. The determination of serum iron by nitroso-r-salt without deproteinization. To be published.

24. Schade, A. L., Oyama, J., Reinhart, R. W., and Miller, J. R. Bound iron and unsaturated ironbinding capacity of serum; rapid and reliable quantitative determination. Proc. Soc. exp. Biol. (N. Y.) 1954, 87, 443.

25. Brecher, G., and Schneiderman, M. A time-saving device for the counting of reticulocytes. Amer. J. clin. Path. 1950, 20, 1079.

26. Nathan, D. G., and Berlin, N. I. Studies of the production and life span of erythrocytes in myeloid metaplasia. Blood 1959, 14, 668.

27. Sterling, K. Radioactive chromium technic for circulating red cell volume. Meth. med. Res. 1960, 8, 69.

28. Melville, G. S., Conte, F. P., and Upton, A. C. Biphasic hyperferremia induced in rats by $\mathrm{X}$-irradiation. School Av. Med. 1957, USAF 57-74.

29. Chanutin, A., and Ludewig, S. Effect of whole body $\mathrm{X}$-irradiation on serum iron concentration of rats. Amer. J. Physiol. 1951, 166, 380. 